\title{
Biopsy of Nasopharynx
}

National Cancer Institute

\section{Source}

National Cancer Institute. Biopsy of Nasopharynx. NCI Thesaurus. Code C51768.

Removal of tissue from the nasopharynx for microscopic examination. 